ISSN 0258-7122 (Print), 2408-8293 (Online)

Bangladesh J. Agril. Res. 44(4): 649-658, December 2019

\title{
DETERMINANTS OF HOUSEHOLD FOOD SECURITY IN RURAL BANGLADESH: AN EMPIRICAL ANALYSIS OF FARM LEVEL DATA
}

\author{
K. S. RAHMAN ${ }^{1}$, M. K. HASAN ${ }^{2}$ AND M. HASAN
}

\begin{abstract}
The study endeavors to estimate the food security status and identify the determinants of food security among households in Hakimpur Upazila in Dinajpur district, Bangladesh. it was found that households of Hakimpur upazila in Dinajpur district were food insecure during the period of the survey. Number of dependents, income of household head, age of household head and level of education were found to significantly influence household head food security in the study area positively. It is recommended that social security measures must ensure that the benefits of public efforts to improve food security and nutrition are universal. Human rights based practices are preferable.
\end{abstract}

\section{Introduction}

Now a day's food security issue is getting more attention in the world. The stability means both the availability and accessibility of food in various dimensions of food. Food security comprised of four components such as food availability, accessibility, utilization and stability. Bangladesh is an over populated country having a population density of 1104 per square kilometer. Agriculture is the most important sector for the economy of Bangladesh contributing $14.74 \%$ to the GDP. The huge population of the country depends on agriculture sector for their foods and calories.

The population growth rate of Bangladesh is $1.03 \%$. According to this rate, the total population will become 233.2 million within 2050. In Bangladesh, about 0.08 million of arable land are going out of production every year (Mondal, 2010). However, the country faces a tremendous challenge for providing food security to the increasing population. Therefore, it is important to increase food production in order to meet the growing demand for food emanating from population growth. Although there are significant achievements in food grain production but, food insecurity both in national and household level remains a matter of major concern in Bangladesh. Like many other developing countries, food security in Bangladesh is also threatened by the global economic crisis and soaring price of essentials. Food security is viewed as the "number one" priority of the government. Poverty is the major factor effecting food security in

${ }^{1}$ Scientific Officer, ${ }^{2}$ Chief Scientific Officer, Agricultural Statistics \& ICT, Bangladesh Agricultural Research Institute (BARI), Gazipur, ${ }^{3}$ Scientific Officer, Farm Machinery and Post-harvest Process Engineering Division, BARI, Gazipur, Bangladesh. 
Bangladesh. According to World food Summit, 1996 food security is defined as "when all people all the times access to sufficient, safe, nutritious food to maintain a healthy and active life." Commonly, the food security is defined as including both physical and economic access to food that meets people's dietary needs as well as their food preferences. Food security is built on three pillars namely, Food availability, Food access and Food use. People are considered food secure when they have availability and adequate access at all times to sufficient, safe, nutritious food to maintain a healthy and active life. Food security analysts look at the combination of the following three main elements such as food availability, food accessibility and food utilization.

Rice is the staple food and its production plays an important role in the economy of the country. In Bangladesh, rice alone constitutes 92 percent of the total food grain production annually. It provides about 80 percent of the people's energy intake (Tetens et al. 2003), the majority of their protein intake, and a considerable proportion of several micronutrients in their average daily diet (Hels et al. 2003). Food availability of a country may depend on some other factor also. Among them, different socio-economic and demographic variables like population, total food production, imports of the food items, per capita income, adult literacy rate, female attending school, male attending school, infant mortality rate, employed labour force are remarkable. Therefore it is our particular interest to investigate the determinants of food security of Bangladesh using econometric time series approach. In this view points a number of studies which have been conducted to investigate such determinants are reviewed are noted bellow.

Gebre (2012) applied logistic regression model to examined the determinants of food insecurity among urban households in Addis Ababa city and pointed out six important factors out of ten factors. The identified significant factors are household size, age of household head, education of the household head, and access to credit, household asset possession, and access to employment. Sultana and Kiani (2011) studied to examine the determinants of household's food security in Pakistan using micro data for the year of 2007-08 and found that place of residence has a significant and negative effect on household's food security status. They also identified that the dependency ratio has a significant impact on food security and has expected sign negative. Educational attainment level of household's head beyond intermediate level has also significant and positive impact on food security status of household. Whereas social capital and employment do not effect household's food security significantly. They advised different policies and programs that should be needed to address for the wellbeing of their people. Some other remarkable research have been cited in the literature [Iram and Butt (2004), Hazarika and Khasnobis (2005); Omotesho et. al., (2010); Arene and Anyaeji (2010); Sisay and Edriss, (2012); Bogale and 
Shimelis (2009) and Mitiku et. al., (2012)] to investigate and idetified some important factors through their research in food security area.

Faridi and Wadood (2010) studied to investigate the determinants of household food security situation in Bangladesh applying the logistic regression. They found different household characteristics which are strongly correlated with food security indicator. They also show that food security indicator is also highly sensitive to rice price changes. Most of the studies have been introduced regression technique. As therefore, it is our particular interest to investigate the determinants of food security of Bangladesh using household level data. Most of the studies have been introduced regression techniques having without or partial involvement of econometric tests may questionable on their application. As therefore, it is our particular interest to investigate the determinants of food security of Bangladesh using Logistic Regression Analysis approach which could be able to meet the existing research gap. Therefore the study is very important to have an idea about the factors affecting food security might help in making decision by the policymakers for policy making in future.

The Specific Objectives of the study are:

(i) To explore the present status of food security in Bangladesh on the basis of availability, accessibility and utilization of food.

(ii) To identify the factors influencing food security/ insecurity in Bangladesh.

(iii) To establish an econometric time series model to forecast the future food security status.

(iv) To formulate policy guidelines/suggestions

\section{Materials and Method}

The study was conducted in Hakimpur (Hili) Upazila in Dinajpur district in Bangladesh. Hakimpur (Hili) is located at the North-Western part of the country and considered as the center of northwestern Bangladesh. Hakimpur (Hili) is an emerging urban center and magnification rate of the urban population has been incrementing at an expeditious rate and commercialization active have been on the incrimination placing most of the inhabitants who are mostly farmers, civil servants, handicrafts worker and traders under economic stress.

\section{Selection of the Study area and Sample Size}

Purposive Simple random sampling techniques were adopted for selecting reasonable numbers of sample from farmers, traders/merchants, handicrafts worker and civil/public servants. At the first stage of Sampling, one districts was selected from 10 most poor districts (Kurigram, Dinajpur, Magura, Bandarban, 
Khagrachari, Shariatpur, Lalmonirhat, Gaibandha, Nilphamari and Thakurgaon) for the study. At the second stage of sampling, one Upazila, Hakimpur was selected purposively for the study. Then sample farmers, traders/merchants, handicrafts worker and Civil/public servants were randomly selected for primary data collection. The population of the study was purposively drawn from respondents who are mainly farmers. Traders/merchants, handicrafts, worker and civil/public servants. A total of 56 respondents were arbitrarily drawn from the Hakimpur (Hili) Upazila in Dinajpur district.

\section{Data/information and Analytical Technique}

Both primary and secondary data and information were used for the study. Primary data were collected from field level through questionnaire survey from the aforesaid locations. Secondary data and information relating to different statistics were gathered from various published Sources like BBS, FAOStat, research reports etc.

Data were analyzed applying descriptive statistics and logistic regression analysis. Firstly, a set of brief descriptive coefficients that summarizes a given data set. Which can either be a representation of the entire population or a sample. The measures used to describe the data set are measures of central tendency and measures of variability or dispersion. Measures of central tendency include the Mean, Median and Mode while measures of variability include the Standard Deviation (or variance), the minimum and maximum variables, Kurtosis and Skewness. Food security status was quantified setting a binary value of one or zero. Where one represents food secure and zero represents food insecure. The logistic regression then provides a model of observing the probability of a household becoming food secure or food insecure.

The logistic model is designated explicitly as:

$$
Y=b_{0}+b_{1} X_{1}+b_{2} X_{2}+b_{3} X_{3}+b_{4} X_{4}+b_{5} X_{5}+b_{6} X_{6}
$$

Where $Y=$ Food security status (1, if household is food secure; 0 ,if household is food insecure)

$$
\begin{aligned}
& \mathrm{X}_{1}=\text { Sex of household head }(\text { Male }=1 ; \text { female }=0) \\
& \mathrm{X}_{2}=\text { Household size }(\text { Member of dependents) } \\
& \mathrm{X}_{3}=\text { Manthly Income of household }(T K) \\
& \mathrm{X}_{4}=\text { Age of household head }(\text { Year }) \\
& \mathrm{X}_{5}=\text { Level of education of household head (Year of schooling) } \\
& \mathrm{X}_{6}=\text { Per Capita monthly food expenditure }
\end{aligned}
$$




\section{Results and Discussion}

Socioeconomic characteristics of the respondents:

Age of the respondents

It was found that the highest percentage $(46.42 \%)$ of the respondents was in the age group of 46-60 years followed by 31-45 years (44.67\%) and age group up to 30 years $(5.36 \%)$ and age group above 60 years has the lowest percentage $(3.58 \%)($ Table 1$)$

\section{Education level of the respondents}

On an average, $10.71 \%$ respondents were illiterate and others having variable levels of academic background. Among the educated respondents $21.43 \%$ had primary level of education, $33.92 \%$ had S S C level of education, $19.65 \%$ had H $\mathrm{S} \mathrm{C}$ level of education, $14.29 \%$ had education at above H.S.C.(Table 1)

Table 1. Socioeconomic characteristics of the respondents

\begin{tabular}{l|c|c}
\hline \multicolumn{1}{c}{ Age : } & No. of the respondents & $\%$ of the respondents \\
\hline Up to 30 years & 3 & $5.36 \%$ \\
31-45 years & 25 & $44.64 \%$ \\
46-60 years & 26 & $46.42 \%$ \\
Above 60 years & 2 & $3.58 \%$ \\
Education : & & \\
Illiterate & 6 & 10.71 \\
Primary & 12 & 21.43 \\
SSC & 19 & 33.92 \\
HSC & 11 & 19.65 \\
Above HSC & 8 & 14.29 \\
\hline
\end{tabular}

\section{Descriptive Statistics}

Descriptive Statistics provide a useful summary of security returns when performing empirical and analytical analysis, as they provide a historical account behavior. Although past information is useful in any analysis, one should always consider the expectations of future events. There are 48 male and 8 female among 56 respondents. 
Table 2. Descriptive Statistics on the selected variable

\begin{tabular}{|c|c|c|c|}
\hline Variables & Maximum & Minimum & Average \\
\hline Number of Dependents & 10 & 1 & 3.694 \\
\hline $\begin{array}{l}\text { Income of Household head } \\
\text { (Tk./Month) }\end{array}$ & 75000 & 3500 & 24022 \\
\hline Age of Household Head & 65 & 28 & 46.34 \\
\hline $\begin{array}{l}\text { Per Capita monthly food } \\
\text { expenditure }\end{array}$ & 9000 & 1200 & 3313 \\
\hline Level of Education & 15 & 0 & 8.304 \\
\hline
\end{tabular}

Source Field Survey 2019

Table 2 shows the descriptive statistics. The variable number of dependents means value is 3.694, and the maximum and the minimum value are 10 and 01 respectively. Consequently, the average income, the maximum income and the minimum income of household head are respectively Tk. 75000, Tk. 3500. Similarly, the respondents average age, maximum age and are respectively 46, 65 and 28. Per Capita monthly food expenditure, the maximum food expenditure and the minimum food expenditure of the household are respectively Tk. 3313, Tk. 9000 and Tk.1200.

\section{Food Security index}

This analysis evaluates the food security status of respondents using per capta expenditure on food (Table 3).

Table 3. Food Security line for the respondents

\begin{tabular}{c|cccccccc}
\hline Respondents & $\begin{array}{c}\text { MPCFE } \\
\text { (Tk.) }\end{array}$ & Stats & & Respondents & $\begin{array}{c}\text { MPCFE } \\
\text { (Tk.) }\end{array}$ & Stats \\
\hline 01 & 2600 & High & & 31 & 3000 & High \\
02 & 2500 & High & & 32 & 3500 & High \\
03 & 3900 & High & & 33 & 2500 & High \\
04 & 4000 & High & & 34 & 2500 & High \\
05 & 4000 & High & & 35 & 2500 & High \\
06 & 5000 & High & & 36 & 8000 & High \\
07 & 3000 & High & & 37 & 2500 & High \\
08 & 3000 & High & & 38 & 2000 & Low \\
09 & 4500 & High & & 39 & 2000 & Low \\
\hline
\end{tabular}




\begin{tabular}{|c|c|c|c|c|c|}
\hline Respondents & $\begin{array}{c}\text { MPCFE } \\
\text { (Tk.) }\end{array}$ & Stats & Respondents & $\begin{array}{c}\text { MPCFE } \\
\text { (Tk.) }\end{array}$ & Stats \\
\hline 10 & 2500 & High & 40 & 1500 & Low \\
\hline 11 & 5000 & High & 41 & 2000 & Low \\
\hline 12 & 2400 & High & 42 & 3000 & High \\
\hline 13 & 2000 & Low & 43 & 2500 & High \\
\hline 14 & 2100 & Low & 44 & 1500 & Low \\
\hline 15 & 1595 & Low & 45 & 1500 & Low \\
\hline 16 & 3000 & High & 46 & 1800 & Low \\
\hline 17 & 2500 & High & 47 & 1800 & Low \\
\hline 18 & 1900 & Low & 48 & 1950 & Low \\
\hline 19 & 2000 & Low & 49 & 3500 & High \\
\hline 20 & 2800 & High & 50 & 1950 & Low \\
\hline 21 & 1900 & Low & 51 & 2000 & Low \\
\hline 22 & 3600 & High & 52 & 2000 & Low \\
\hline 23 & 7500 & High & 53 & 9000 & High \\
\hline 24 & 6900 & High & 54 & 3500 & High \\
\hline 25 & 7500 & High & 55 & 1200 & Low \\
\hline 26 & 2200 & Low & 56 & 1950 & Low \\
\hline 27 & 4500 & High & Total & 185545 & \\
\hline 28 & 7500 & High & Mean MPCFE & 3313.304 & \\
\hline 29 & 7500 & High & 2/3MPCFE & 2208.869 & \\
\hline 30 & 5000 & High & Source: field Sur & $y, 2019$ & \\
\hline
\end{tabular}

Note: Mean per Capita Food Expenditure = MPCFE in TK

The analysis ascertained that more than the respondents $(37.5 \%)$ are food insecure since their monthly per capita food expenditure falls below two-third $(2 / 3)$ of the mean monthly per capita food expenditure.

\section{Logistic Regression Analysis Result}

The logistic regression analysis identified the factors affecting the ability of the households to secure available food supplies .the result of analysis is demonstrated in Table 4. 
Table 4. Logistic Regression Result for the Determinants of food Security status

\begin{tabular}{|c|c|c|c|c|}
\hline \multirow[b]{2}{*}{ Explanatory variable } & \multirow[b]{2}{*}{ Coefficients } & \multirow[b]{2}{*}{ Standard } & \multirow[b]{2}{*}{ Z-Statistics } & \multirow[b]{2}{*}{$\operatorname{Pr}(>\mathrm{z})$} \\
\hline & & & & \\
\hline Sex of household head & 0.06138 & 1.181 & 0.520 & 0.60332 \\
\hline $\begin{array}{l}\text { Number of dependents or } \\
\text { household size }\end{array}$ & -1.227 & 0.4598 & $-2.669 * *$ & 0.00761 \\
\hline Income of household head & 0.000175 & 0.0000643 & $2.732 * *$ & 0.00630 \\
\hline Age & -0.1229 & 0.05911 & $-2.078^{*}$ & 0.03768 \\
\hline Level of education & -0.1557 & 0.1332 & $-1.168^{*}$ & 0.04261 \\
\hline $\begin{array}{l}\text { Per capita monthly food } \\
\text { expenditure }\end{array}$ & -0.0005415 & .0003338 & 1.622 & 0.10474 \\
\hline Constant & 6.825 & 3.829 & 1.782 & 0.07472 \\
\hline chi-square & 39.182 & & & \\
\hline $\mathrm{R}^{2}$ & 67.22 & & & \\
\hline
\end{tabular}

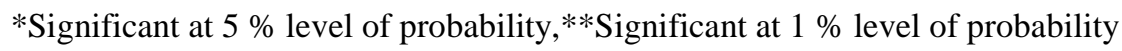

Source: field survey, 2019

Four Variables are important in explaining the food security status of the household . They are number of dependents, income of household head, age of household head and level of education. The other variables demonstrate not to be important. Sex of household head has a negative impact on food security status because more dependents want more food with in the household with a fixed income of household head. Income of household has positive effect on food security status suggesting that the more gainfully employed a household head is, the greater his or her chances of being food secure. The level of education has positive effects on food security status point toward that higher of level education has a greater chance to get a better job, which indirectly helps to earn higher income. Higher income also has positive effects on food security status

In brief, it is yielded that number of dependents, income of household head, age of household head and level of education of the households are the determinants of food security status among the responds of Hakimpur Upazila in Dinajpur District. The coefficient of determination, $\mathrm{R}^{2}$ is 67.22 percent inferring that the variation in food security status is due to the stated socio-economic characteristics of Hakimpur Upazila in Dinajpur District households. The result further showed that the overall logistic model was significant based on the chisquare. Thus representing that the explanatory variables are relevant in determining the household food security status. 


\section{Conclusion}

The study has found that households of Hakimpur Upazila in Dinajpur District were food insecure during the period of the survey. Number of dependents, income of household head, age of household head and level of education were found to significantly influence household head food security in the study area positively. However, sex of household head, Per Capita monthly food expenditure was found to influence food security negatively at the household level.

Based on the results, It is recommended that social security measures must ensure that the benefits of public efforts to improve food security and nutrition are universal. Human rights based practices are preferable. Extremely versatile, tolerant and nutrient-sensitive, it is vital to grow agriculture.

\section{References}

Arene, C.J. and R. C. Anyaeji, (2010): Determinants of Food Security among Households in Nsukka Metropolis of Enugu State, Nigeria. Pakistan Journal of Social Sciences 30(1):9

Bogale A., and A.Shimelis, (2009); Household level determinants of food insecurity in rural areas of Dire Dawa, Eastern Ethiopia, African Journal of food, agriculture nutrition and development. 9(9):1915-1926.

Faridi. R.and S. N. Wadood. 2010. An Econometric Assessment of Household Food Security in Bangladesh. The Bangladesh Development Studies 33(3):97-111.

Gebre, G. G. 2012. Determinants of food insecurity among households in Addis Ababa city, Ethiopia. Interdisciplinary Description of Complex Systems 10(2):159-173.

Hazarika, G. and B. Khasnobis. 2005. Women's status and children's food security in Pakistan. Department of Business Administration, University of Texas.

Hels, O., N.Hassan, I. Tetens, and S. H. Thilsted. 2003. Food consumption, energy and nutrient intake and nutritional status in rural Bangladesh: Changes from 1981-82 to 1995-96. Eur. J. Clin.Nutr. 57: 586-594.

Iram, U., and M.S. Butt. 2004. Determinants of household food security: an imperial analysis for Pakistan. International Journal of Social Economics. 31(8):753-766.

Mitiku, A., B. Fufa, and B. Tadese. 2012. Empirical analysis of the determinants of rural households food security in Southern Ethiopia: The case of Shashemene District. Basic Research Journal of Agricultural Science and Review. 1(6):132-138

Mondal, M H. 2010. Crop agriculture of Bangladesh: Challenges and opportunities. Bangladesh J. Agril. Res. 35(2): 235-245.

Omotesho O. A; M.O. Adewumi and K.S. Fadimula. 2010. Food Security and Poverty of the Rural Households in Kwara State, Nigeria. Libyan Agriculture Research Center Journal International 1(1): 56-59

Sisay, E. and , A. K. Edriss. 2012. Determinants of Food Insecurity in Addis Ababa City, Ethiopia. Journal of Economics and Sustainable Development 3(3):2222-2855 
Sultana A. and A. Kiani. 2011. Determinants of food security at household level in Pakistan, African Journal of Business Management 5(34):12972-12979.

Tetens I, O Hels, NL Khan, SH Thilsted, N Hassan. 2003. Rice-based diets in rural Bangladesh: How do different age and sex groups adapt to seasonal changes in energy intake? Am. J. Clin. Nutr. 78: 406-413. 